\title{
Histopathological and some biochemical effects of platinum drug on the liver and kidney of pregnant mice Mus musculus and their embryos
}

\author{
B.A. Salah $\odot$ and H.S. Sadoon $\odot$ \\ Department of Biology, College of Education for Pure Science, University of Mosul, Mosul, Iraq
}

\begin{tabular}{l} 
Article information \\
\hline Article history: \\
Received March 12, 2020 \\
Accepted April 28, 2020 \\
Available online February 22, 2021 \\
\hline Keywords: \\
Platinum \\
Pregnancy \\
Fetuses \\
Liver \\
Kidney \\
\hline Correspondence: \\
B.A. Salah \\
baidaammmed@uomosul.edu.iq
\end{tabular}

This is an open access article under the CC BY 4.0 license (http://creativecommons.org/licenses/by/4.0/).

DOI: 10.33899/ijvs.2020.126706.1364, (C2021, College of Veterinary Medicine, University of Mosul.

\begin{abstract}
The current study was done to investigate the effects of two doses 3 and $6 \mathrm{mg} / \mathrm{kg}$ B.w. of the Platinum drug on the structure of the liver and kidney of pregnant mice, and embryos in addition to the weight of the mothers, embryos, maternal liver and kidneys, as well as some biochemical parameters, were established. For this study, thirty pregnant mice were used, divided into three groups (10 mice/group) as follows; group I (control group); animals were injected intraperitoneally (IP) with distilled water on the days 7 th, 12th, and 17th of gestation. The other both groups II, and III were injected intraperitoneally (IP) with the selected doses above of the Platinum at the days 7th, 12th, and 17th of gestation, respectively. Microscopically, maternal and fetal' liver sections of group II revealed vacuolation, swelling, apoptosis, infiltration of inflammatory cells, congestion, degeneration, and presence of the extramedullary hematopoietic cells, respectively. Previous lesions were increased in group III. Maternal and, fetal kidney sections of group II revealed degeneration, expansion of Bowman's space, inflammatory cells infiltration into interstitial tissue, and blood capillaries congestion. However, the previous lesions showed more severity in group III. The drug caused a reduction in the body weight of the mothers, selected organs, and embryos. Biochemical assessment of the maternal serum AST, ALT, and ALP levels showed an increase in both experimental groups II and III, but to varying degrees. Moreover, both groups II and III showed an increase in the levels of the maternal BUN and, urea. Whist, group III showed a significant increase of the creatinine compared to the control group. In conclusion, using anticancer drugs during pregnancy will harm both mothers and fetal organs. The risk of these medications represents their ability to cross the placenta and enters the fetal body. Therefore, the drug may affect the formation of the fetal organs. The drug also alters the regulatory antioxidant mechanism in the maternal body during the treatment duration. The drug should be used under medical follow up.
\end{abstract}

\section{Introduction}

Platinum is a metallic collaboration compound, belongs to the class of platinum-based antitumour drugs, these drugs are used in the treatment of many types of cancers such as germ cell tumours, ovarian cancer, cervical cancer, testicular cancer (1). Platinum is a water-soluble inorganic divalent agent (2), and classified as an alkylating - like factor. Platinum is given by injection into a vein (IV) or directly into the peritoneal cavity (IP), (3). Cancer is a time disease. The rate of cancer occurrence during gestation is increasing day after day. Treating pregnant women with drugs was considered one of the causes of cancer (4). Chemical treatment was used in cancer therapy during gestation because of its effective results. Furthermore, the safety of using it during this critical period has not sufficiently studied. Platinum is a good choice for treating cancer during gestation, except that the drug can kill rapidly proliferating 
cells, and the fetus represented just as a rapidly proliferating cell mass (5), as well as the possibility of affecting the maternal organs and impairing fetal development (6). The drug promotes cytotoxicity by forming covalent bonds with nucleophile purine -N7 sites in DNA, it also affects DNA replication, transcription and induces cell death (7), nephrotoxicity, and hepatotoxicity (8), especially if high doses were used (9). The previous data confirmed that the use of anticancer drugs during pregnancy, especially during the first trimester may cause a structural, and a functional disturbance in both mother and fetus bodies (10-12), it also may cause early delivery, intracranial bleeding because the drug can be easily absorbed, and transferred to the fetus through the placenta. The drugs used to treat cancer, although they destroy cancer cells, they cause abnormal changes in the normal cells of the vital organs, especially those responsible for detoxification such as liver and kidney (13). Exposure to the high doses of anticancer gives rise to the rate of oxidative stress in both liver, and kidney of rodents, as well as promotes ovary problems in women $(14,15)$. The drug accumulates in the mitochondria, and induces cellular mitochondrial damage that has a teratogenic effect on the mouse embryonic development $(16,17)$. The current study aimed to investigate the toxic effects of the doses 3 and $6 \mathrm{mg} / \mathrm{kg}$ of b.w. of a Platinum drug on the liver, kidneys of both pregnant mice Mus musculus and their fetuses, in addition to the body weight of the mothers, selected organs, and the fetuses. The pregnant mice were injected with certain doses intraperitoneally (IP) on the days $7^{\text {th }}, 12^{\text {th }}$, and $17^{\text {th }}$ of pregnancy as a one single dose per day. Moreover, some biochemical variables were measured in the maternal serum to evaluate the sufficiency of both maternal liver, and kidney functions.

\section{Materials and methods}

\section{Animal husbandry}

Thirty pregnant mice Mus musculus weighted $29 \pm 3 \mathrm{gm}$ at age $60 \pm 4$ days were used in the current study. The study was conducted within 4 months. Animals were brought from the animal's house of the College of Veterinary Medicine, Mosul University, and Mosul, Iraq. All animals were housed in standard plastic cages with free access to their food and water. They were kept in the animals' house of the department of Biology, College of Education for Pure Science. They exposed to an equal day/night cycle, at $23 \pm 3^{\circ} \mathrm{C}$. Animals were treated following the care and the use of laboratory animal guides. For mating, both males and females were caged together for overnight (one male / two female per cage) (18). The presence of a vaginal plug was examined early in the morning, and considered as the first day of pregnancy (19). Selected mice were isolated in separated cages. The drug used in the present study was the Platinum (Cis-diamminedichloroplatinum) injection solution $(50 \mathrm{mg} / 100 \mathrm{ml})$ produced by Kang Pharmacy, Haryana, India.

\section{Experimental design}

Pregnant mice were divided into three groups (each group consisted of 10 pregnant mice), as the following; group I: (control group) was injected intraperitonialy (IP) with $0.2 \mathrm{ml}$ of distilled water at the days $7^{\text {th }}, 12^{\text {th }}$, and $17^{\text {th }}$ of pregnancy for once. Group II: injected (IP) with $3 \mathrm{mg} / \mathrm{kg}$ of b.w. of Platinum at the days $7^{\text {th }}, 12^{\text {th }}$, and $17^{\text {th }}$ of pregnancy for once. Group III: injected (IP) with $6 \mathrm{mg} / \mathrm{kg}$ of b.w. of Platinum at the days $7^{\text {th }}, 12^{\text {th }}$ and $17^{\text {th }}$ of pregnancy for once. The doses were withdrawn from the drug solution by insulin syringe $(0.1 \mathrm{ml})$. The volume of the doses was determined to be appropriate for the weight of pregnant mice. The selected doses were chosen depending on the LD50 of the Platinum, which is $7.5 \mathrm{mg} / \mathrm{kg}$ of b.w. for mice (20).

\section{Specimens preparation and examination}

Pregnant mice were euthanized, and dissected on the $17^{\text {th }}$ day of pregnancy. Fetuses, liver, kidney of both mothers and fetuses were isolated, weighed, and washed with distilled water. All specimens were fixed with formalin $10 \%$ fixative for 48 hours. After fixation, the specimens were washed with distilled water for 2 hours, and the samples were processed routinely. Sections were stained with Delafield's Hematoxylin and Eosin. The slides were mounted with DPX (21). The histological examination was done using an optical microscope. For photography, a digital camera was used (type MDCE-5A, Japan). The camera was connected to the optical lens of the microscope. Blood samples were collected using a method of the retro-orbital plexus prior to dissection. Collected blood was kept in the anticoagulant tubes. The serum was prepared using the standard method used in the biochemical laboratories.

\section{Biochemical evaluation of maternal liver and kidney functions}

The activities of alanine transferase (ALT), alkaline phosphatase (AIP), and aspartate aminotransferase (AST) enzymes were measured using the antioxidant assay kit (Sigma-Aldrich, C50790) to evaluate the efficiency of the maternal liver function. Furthermore, Urea, uric acid, creatinine, and blood urea nitrogen (BUN) were measured using commercial kits (Biomerieux, France) to evaluate the competence of maternal kidney.

\section{Data analysis}

The current data including; weight changes in the body of mothers and fetuses, selected organs, and activities of maternal liver and kidney biomarkers were expressed as mean \pm standard deviation (SD). The data were statistically analyzed using one -way ANOVA (one -way analysis of variance). Dunnett's test (multiple comparison method) was used to indicate the differences by comparing the means of 
each experimental groups II, and III with the mean of the control group I. The statistical estimations of the current data were achieved using statistical software Graph Pad Prism 5.0 (San Diego, USA). The significance level was set at $* \mathrm{P}<0.05$ is significant, $* * \mathrm{P}<0.01$; a highly significant, and $* * *$ $\mathrm{P}<0.001$; a very highly significant.

\section{Results}

\section{Histopathological observations of the maternal and fetal liver}

Light microscopic examination of the control liver sections of pregnant mice showed normal liver tissue composed of central vein, and hepatocytes (Figure 1).

Liver sections of the mothers' group II showed; vacuolation of hepatocytes, congestion of the central vein (Figure 2). Moreover, apoptosis, and necrosis of some hepatocytes also were observed (Figure 3).

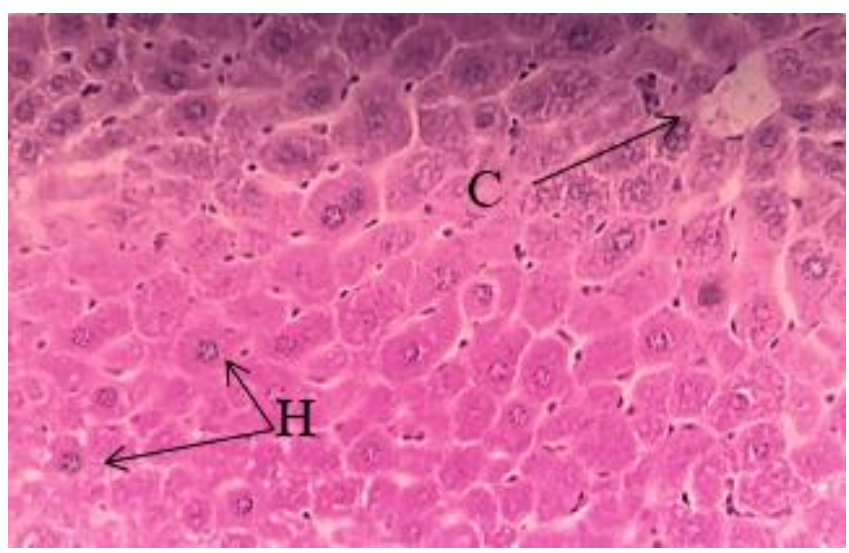

Figure 1: Cross-section of pregnant mice Mus musculus liver (control) showing; normal liver tissue composed of the central vein (C), and normal hepatocytes (H). (H\&E, 400X).

At the dose of $6 \mathrm{mg} / \mathrm{kg}$ of b.w. of Platinum, the lesions were increased, and represented with the dilatation of sinusoids, an increase in the eosinophil's, and vacuolation of hepatocytes (Figure 4). Furthermore, congestion of the portal vein, and infiltration of the inflammatory cells were observed in the portal area (Figure 5).

The light microscope examination of the fetal liver of the control group I revealed; normal hepatic primitive tissue (Figure 6).

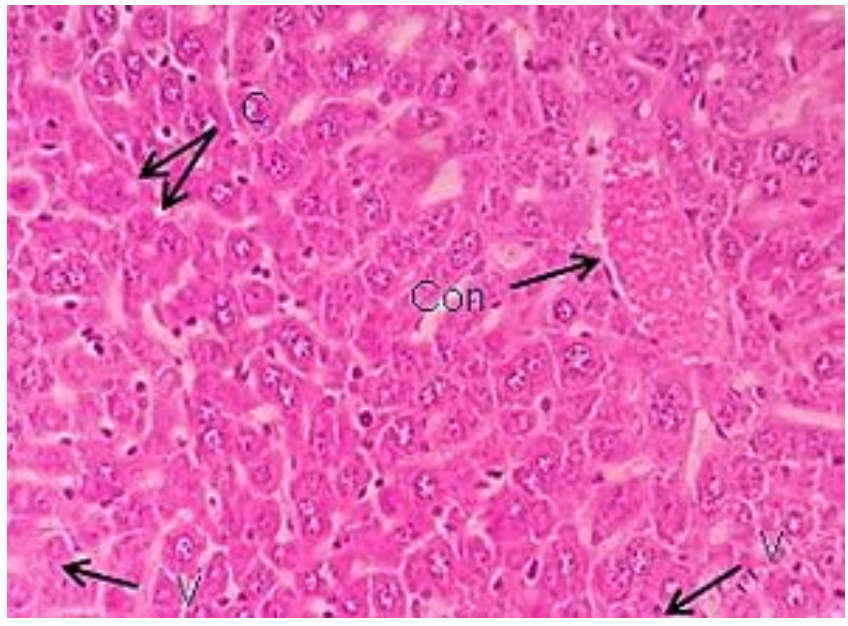

Figure 2: Cross-section of pregnant mice Mus musculus liver injected (IP) with a Platinum drug at the dose of $3 \mathrm{mg} / \mathrm{kg}$ of b.w. on the days $7^{\text {th }}, 12^{\text {th }}$, and $17^{\text {th }}$ of pregnancy showing; vacuolation $(\mathrm{V}, \mathrm{C})$ of hepatocytes, and congestion (Con) of the central vein. (H\&E, $400 \mathrm{X})$.

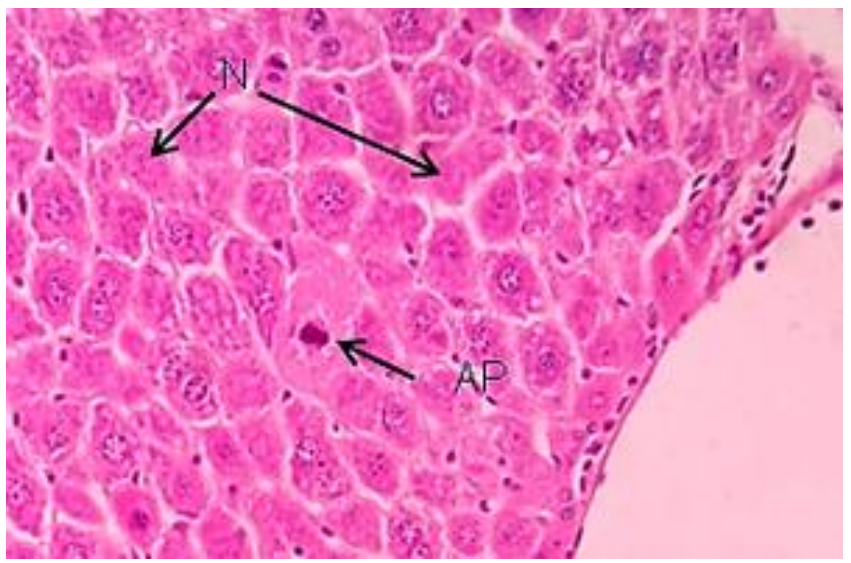

Figure 3: Cross-section of pregnant mice Mus musculus liver injected (IP) with a Platinum drug at the dose of $3 \mathrm{mg} / \mathrm{kg}$ of b.w. on the days $7^{\text {th }}, 12^{\text {th }}$, and $17^{\text {th }}$ of pregnancy showing; apoptosis (AP), and necrosis $(\mathrm{N})$ of some hepatocytes. (H\&E, $400 \mathrm{X})$.

Fetal liver sections of mothers' group II showed; congestion of the blood capillaries between hepatocytes, presence of extramedullary hematopoietic cells, and mild degeneration of the primitive hepatocytes (Figure 7).

At the dose of $6 \mathrm{mg} / \mathrm{kg}$ of b.w. congestion was increased (Figure 8), and primitive hepatocytes showed severe degeneration (Figure 9). 


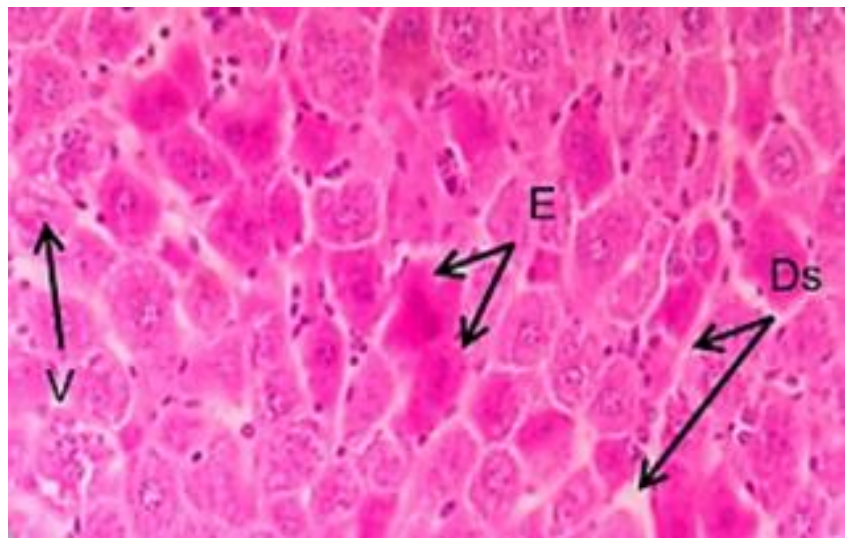

Figure 4: Cross-section of pregnant mice Mus musculus liver injected (IP) with a Platinum drug at the dose of $6 \mathrm{mg} / \mathrm{kg}$ of b.w. at the days $7^{\text {th }}, 12^{\text {th }}$, and $17^{\text {th }}$ of pregnancy showing; dilatation of sinusoids (DS), increase in the eosinophil's (E) ,and vacuolation (V) of hepatocytes. (H\&E, 400X).

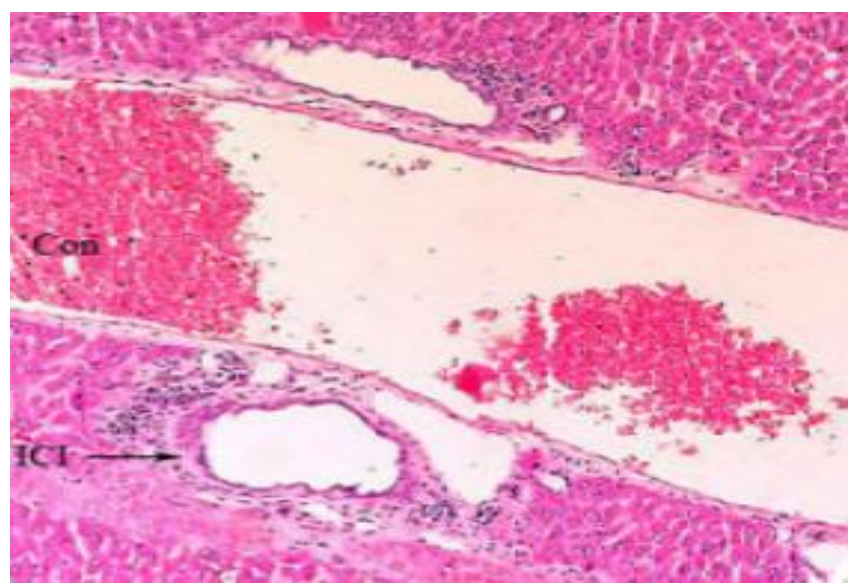

Figure 5: Cross-section of pregnant mice Mus musculus liver injected (IP) with a Platinum drug at the dose of $6 \mathrm{mg} / \mathrm{kg}$ of b.w. at the days $7^{\text {th }}, 12^{\text {th }}$, and $17^{\text {th }}$ of pregnancy showing; congestion of the portal vein (Con), Inflammatory cells infiltration (ICI) in the portal area. (H\&E, 400X).

\section{Histopathological observations of the maternal and fetal kidneys}

Light microscope examination of the maternal kidney sections of the control group I showed; normal renal tissue composed of glomerulus, and renal tubules (Figure 10).

Sections from mothers group II showed; degeneration of proximal convoluted tubules epithelium, and expansion of Bowman's space (Figure 11).

Moreover, kidney sections of mothers' group III showed; an increase in the inflammatory cells infiltration in the interstitial tissue, and severe degeneration of the proximal convoluted tubules epithelium (Figure 12).

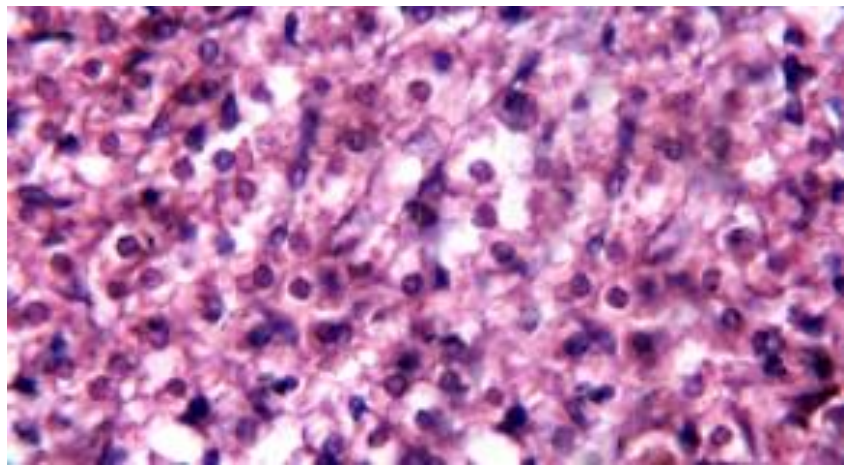

Figure 6: Cross-section of the fetal liver of pregnant mice Mus musculus (control) showing; normal hepatic primitive tissue. (H\&E, $400 \mathrm{X}$ ).

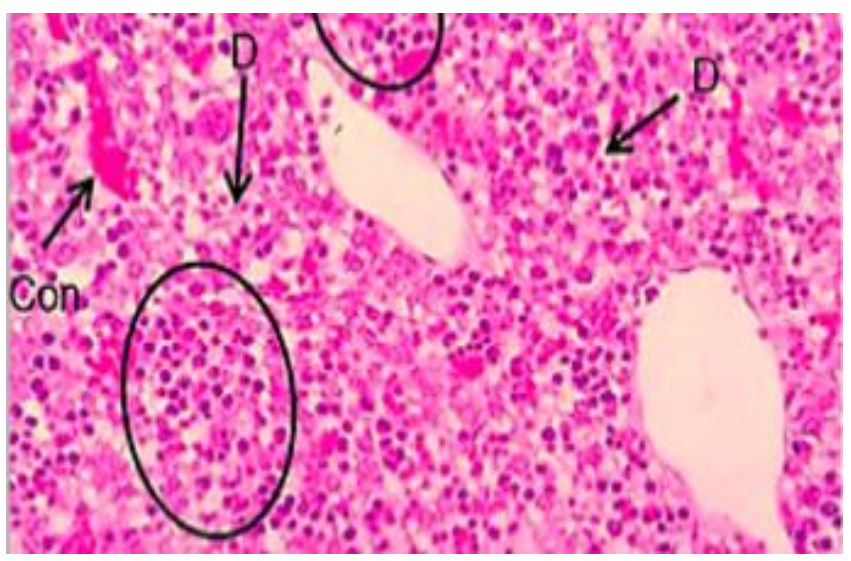

Figure 7: Cross-section of the fetal liver of pregnant mice Mus musculus injected (IP) with a Platinum drug at the dose of $3 \mathrm{mg} / \mathrm{kg}$ of b.w. on the days $7^{\text {th }}, 12^{\text {th }}$, and $17^{\text {th }}$ of pregnancy showing; congestion (Con), extramedullary hematopoietic cells (circles), and degeneration (D) of the primitive hepatocytes. (H\&E, $400 \mathrm{X}$ ).

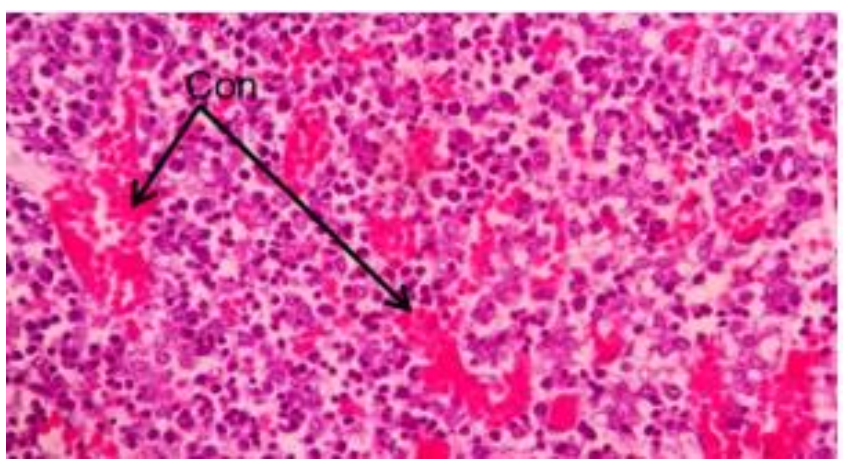

Figure 8: Cross-section of the fetal liver of pregnant mice Mus musculus injected (IP) with a Platinum drug at the dose of $6 \mathrm{mg} / \mathrm{kg}$ of b.w. on the days $7^{\text {th }}, 12^{\text {th }}$, and $17^{\text {th }}$ of pregnancy showing; an increase in the congestion (Con). (H\&E, 400X). 


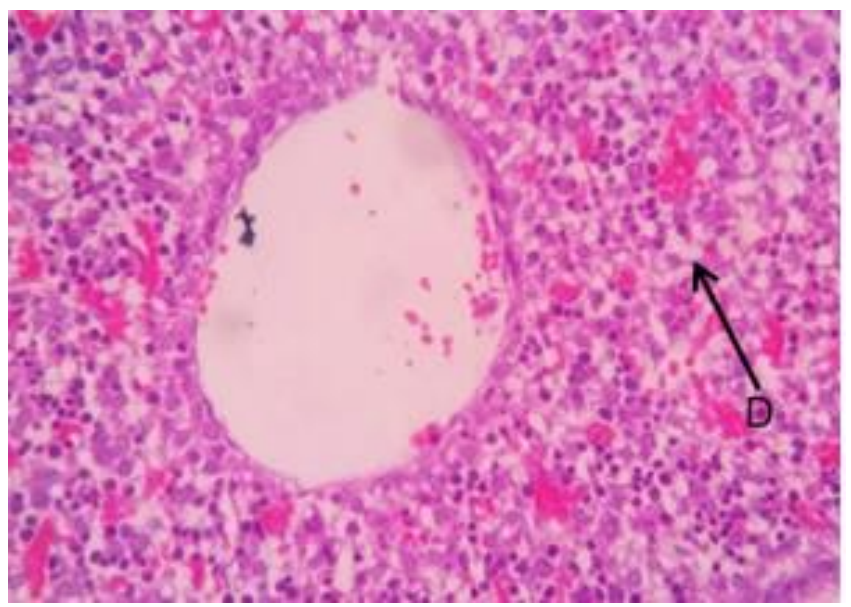

Figure 9: Cross-section of the fetal liver of pregnant mice Mus musculus injected (IP) with a Platinum drug at the dose of $6 \mathrm{mg} / \mathrm{kg}$ of b.w. at the days $7^{\text {th }}, 12^{\text {th }}$, and $17^{\text {th }}$ of pregnancy showing; severe degeneration (D) of the primitive hepatocytes. (H\&E, 400X)

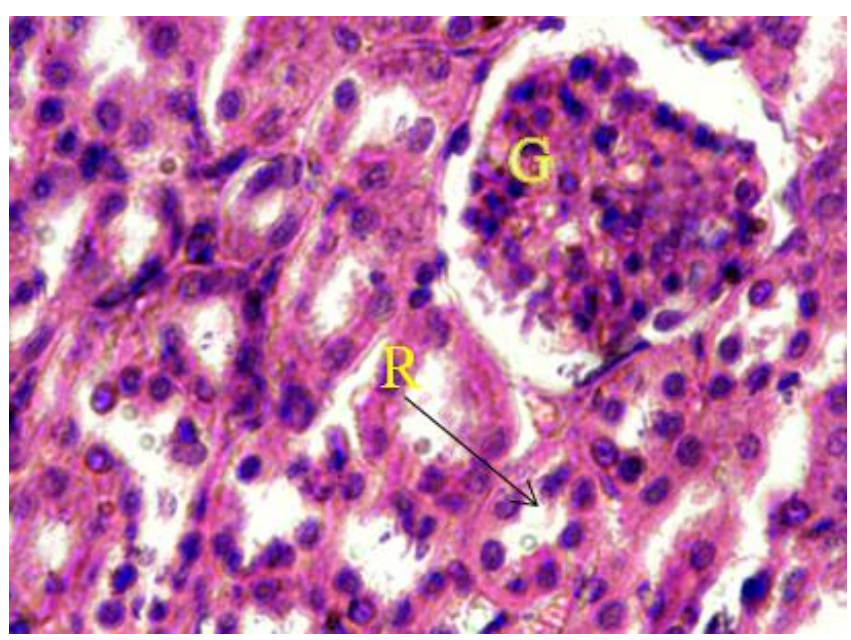

Figure 10: Cross-section of pregnant mice Mus musculus kidney (control) showing; normal renal tissue composed of glomerulus $(\mathrm{G})$, and renal tubules $(\mathrm{R})$. (H\&E, 400X).

Microscopical examination of the fetal kidney of the control group I showed; normal renal primitive tissue composed of primitive renal tubules, and primitive glomerulus (Figure 13).

Sections from mothers group II showed; degeneration of the primitive tubules epithelium, and congestion of the blood capillaries within the interstitial tissue (Figure 14).

Sections of mothers group III showed; an increase in the degeneration of the primitive renal tubules epithelium, and an increase in the congestion of the blood capillaries within the interstitial tissue (Figure 15).

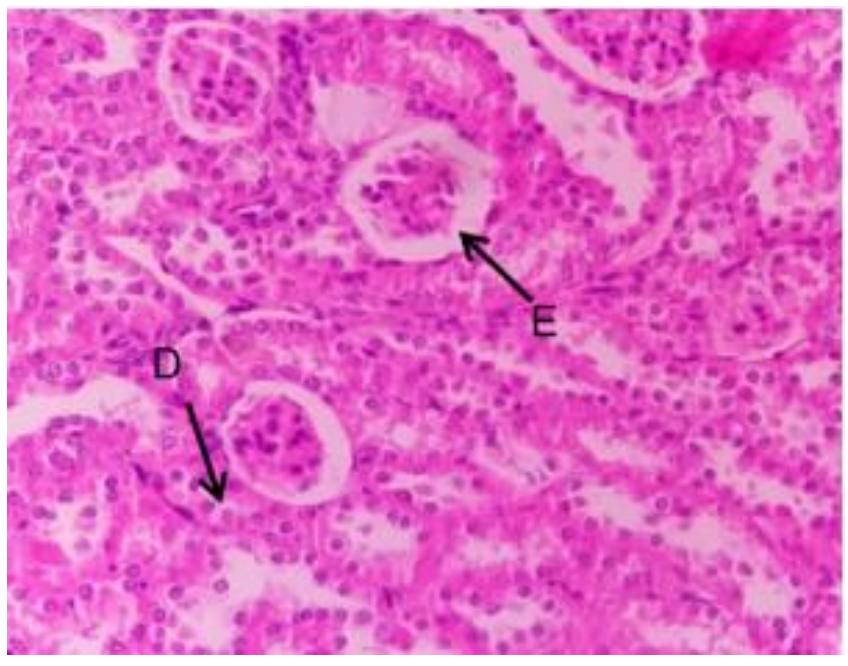

Figure 11: Cross-section of pregnant mice Mus musculus kidney injected (IP) with a Platinum drug at the dose of 3 $\mathrm{mg} / \mathrm{kg}$ of b.w. on the days $7^{\text {th }}, 12^{\text {th }}$, and $17^{\text {th }}$ of pregnancy showing; degeneration (D) of proximal convoluted tubules epithelium, and expansion of Bowman's space (E). (H\&E, 400X)

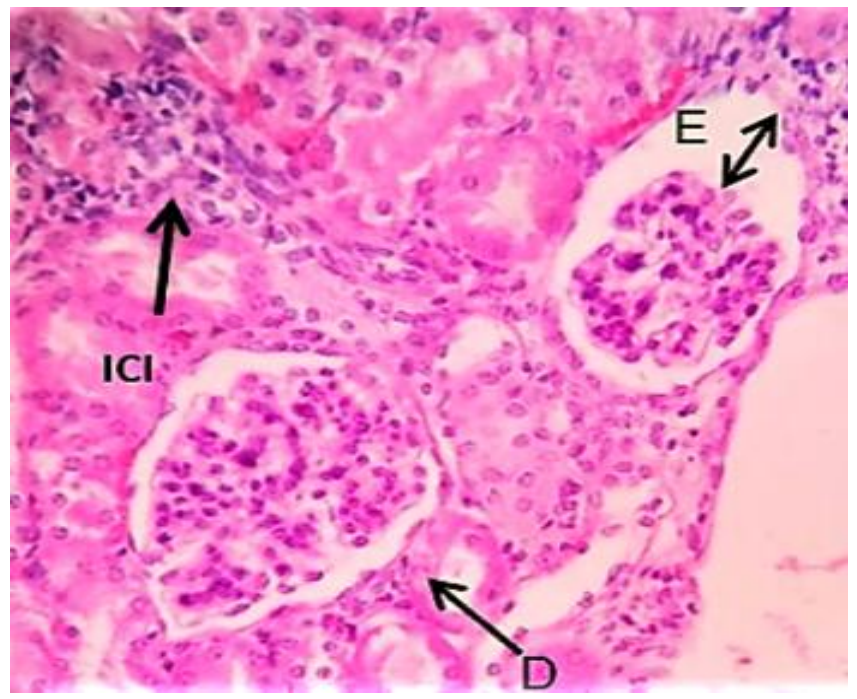

Figure 12: Cross-section of pregnant mice Mus musculus kidney injected (IP) with a Platinum drug at the dose of 6 $\mathrm{mg} / \mathrm{kg}$ of b.w. on the days $7^{\text {th }}, 12^{\text {th }}$, and $17^{\text {th }}$ of pregnancy showing; an increase in the inflammatory cells infiltration in the interstitial tissue (ICI), and degeneration (D) of proximal convoluted tubules epithelium. (H\&E, 400X). 


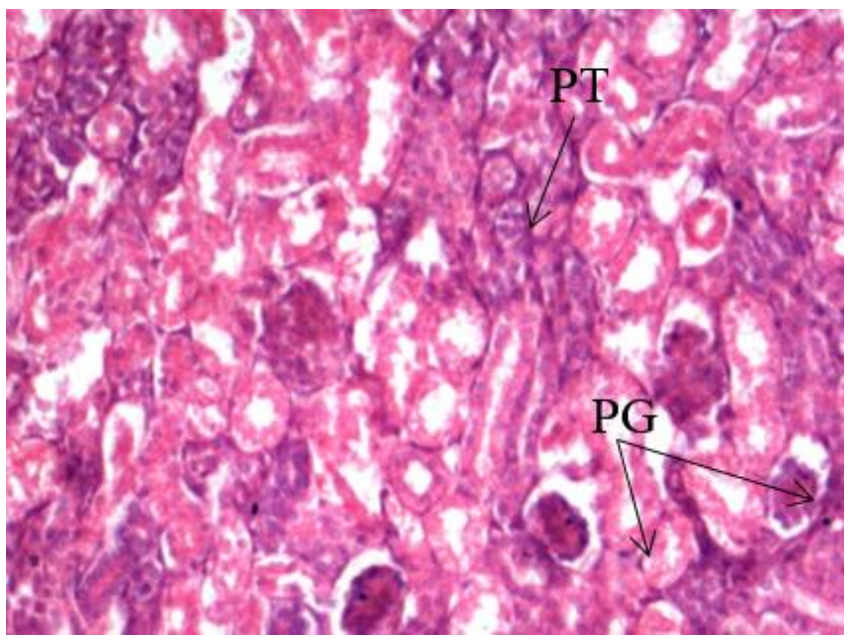

Figure 13: Cross-section of the fetal kidney of pregnant mice Mus musculus (control) showing; normal renal primitive tissue composed of primitive renal tubules (PT), and primitive glomerulus (PG).(H\&E, 400X).

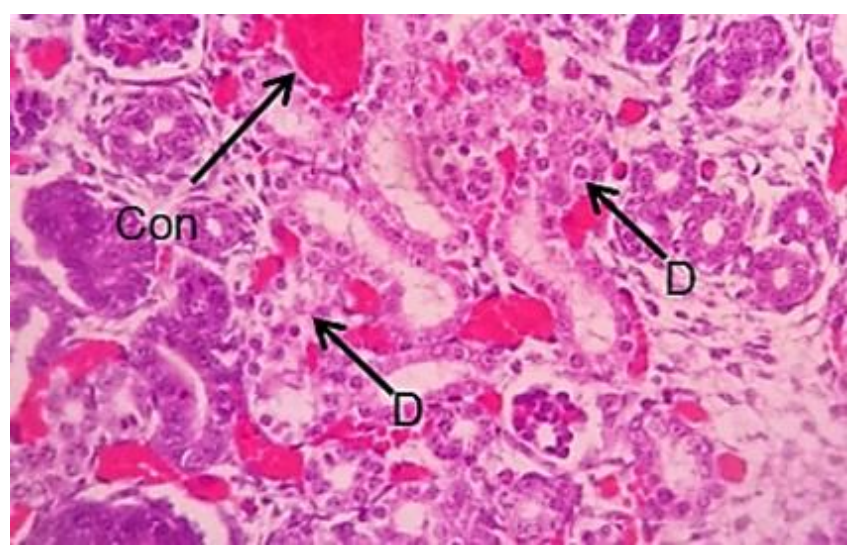

Figure 14: Cross-section of the fetal kidney of pregnant mice Mus musculus injected (IP) with a Platinum drug at the $3 \mathrm{mg} / \mathrm{kg}$ of b.w. on the days of $7^{\text {th }}, 12^{\text {th }}$, and $17^{\text {th }}$ of pregnancy showing; degeneration (D) of primitive renal tubules epithelium, and congestion (Con) of blood capillaries within the interstitial tissue. (H\&E, 400X).

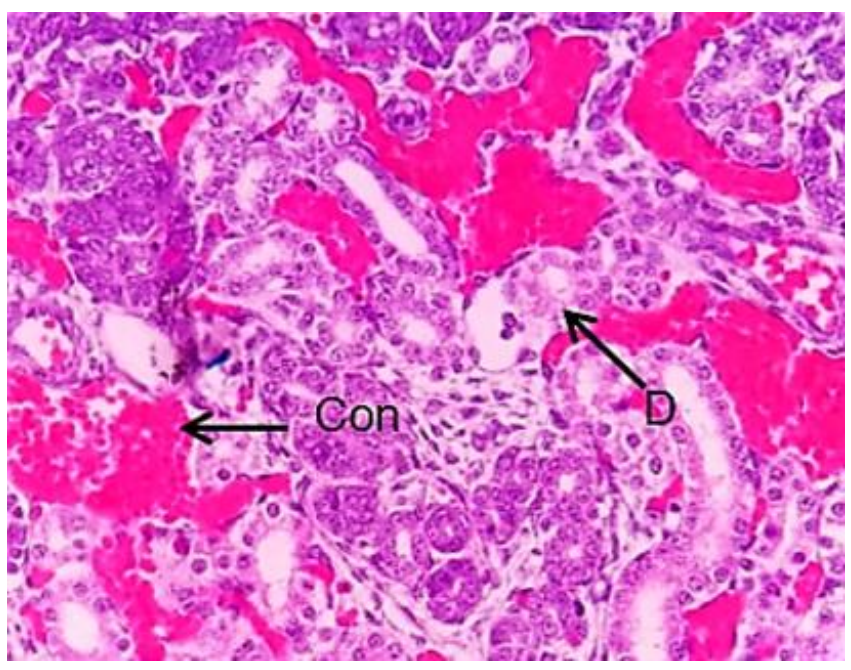

Figure 15: Cross-section of the fetal kidney of pregnant mice Mus musculus injected ( IP) with a Platinum drug at the $6 \mathrm{mg} / \mathrm{kg}$ of b.w. on the days of $7^{\text {th }}, 12^{\text {th }}$, and $17^{\text {th }}$ of pregnancy showing; an increase in the degeneration (D) of the primitive renal tubules epithelium, and an increase in the congestion (Con) of the blood capillaries in the interstitial cells. (H\&E, 400X).

\section{Weight changes}

Throughout the experimental period, all groups I, II and III were weighted twice in the days $7^{\text {th }}$ and $17^{\text {th }}$ of pregnancy. Both groups II, and III showed a significant reduction $\mathrm{P}<$ 0.05 , and a highly reduction $\mathrm{P}<0.01$ in maternal body weight compared to the control group, respectively. Maternal liver of both groups II, and III did not show any change in their weight compared to the control group I, respectively. Group III showed a significant decrease $\mathrm{P}<0.05$ in the maternal kidney weight, but group II did not report any weight changes compared to the control group I, respectively. Furthermore, There had been a highly decrease $\mathrm{P}<0.01$, and a non-significant decrease in the fetal body weight of both groups II, and III compared to control group I, respectively (Table 1).

Table 1: Illustrates the effect of two doses 3 and $6 \mathrm{mg} / \mathrm{kg} \mathrm{b.w.} \mathrm{of} \mathrm{Platinum} \mathrm{administrated} \mathrm{to} \mathrm{the} \mathrm{pregnant} \mathrm{mice} \mathrm{at} \mathrm{the} \mathrm{days} 7^{\text {th }}$, $12^{\text {th }}$, and $17^{\text {th }}$ of gestation on the maternal weight of the body, liver, kidneys, and the fetal body weight

\begin{tabular}{lccc}
\hline & Control & Group II & Group III \\
\hline Mean Body Weight on the $7^{\text {th }}$ day & $26.54 \pm 0.45$ & $27.1 \pm 1.07$ & $27.04 \pm 0.21$ \\
Mean body Weight on the $17^{\text {th }}$ day & $29.91 \pm 0.94$ & $27.56 \pm 1.06^{*}$ & $26.85 \pm 1.17^{* *}$ \\
Mean Liver Weight on the $17^{\text {th }}$ day & $2.14 \pm 0.21$ & $2.09 \pm 0.73$ & $1.79 \pm 0.43$ \\
Mean Kidney Weight on the $17^{\text {th }}$ day & $1.58 \pm 0.29$ & $1.48 \pm 0.28$ & $1.06 \pm 0.12^{*}$ \\
Mean foetus Weight on the $17^{\text {th }}$ day & $1.32 \pm 0.06$ & $1.22 \pm 0.16$ & $0.96 \pm 0.11^{* *}$ \\
\hline
\end{tabular}

All values were expressed with mean \pm standard deviation $(\mathrm{SD})$, the significance level was estimated at; $* P<0.05$; significant, and $* * P<0.01$; a highly significant. Dunnett's test was employed to determine the differences by examining each mean of groups II, and III with the mean of the control group I. 


\section{Effect of Platinum on the maternal liver and kidney functions}

The biochemical estimation of the maternal serum of both groups II, and III showed; a highly significant increase $\mathrm{P}<0.01$, and non-significant changes in the activity of AST compared to the control group I, respectively. ALT levels of both groups III, II showed a very highly significant increase $\mathrm{P}<0.001$, and a highly significant increase $\mathrm{P}<0.01$ compared to the control group I, respectively. ALP activity showed a significant increase $\mathrm{P}<0.05$ in the group III, while group II showed a non-significant increase compared to the control group I, respectively (Figure 16).

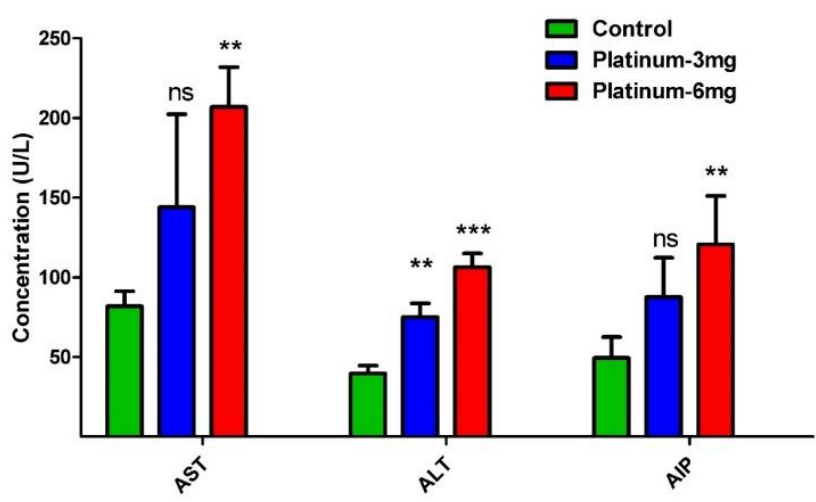

Figure 16: Explaining the impact of two doses 3 and $6 \mathrm{mg}$ $/ \mathrm{kg}$ b.w of Platinum administrated to the pregnant mice at the days $7^{\text {th }}, 12^{\text {th }}$, and $17^{\text {th }}$ of gestation on the levels of motherly serum enzymes including; AST, ALT, and ALP. The data were expressed as mean \pm standard deviation (SD), and $\mathrm{n}=$ three. All values were considered significant at $* \mathrm{P}<0.05$, a highly significant at $* * \mathrm{P}<0.01$, a very highly significant at $* * * \mathrm{P}<0.001$, and ns- non-significant compared to the control group I. Dunnett's test was employed to show the differences by comparing the mean of each enzyme of both experimental groups II, and III with the mean of control group I.

Biochemical testing of the maternal serum that performed to assess the competence of the kidney functions, clearly demonstrated; a highly significant increase of $\mathrm{P}<$ 0.01 in the BUN levels of both groups II, and III compared to control group I, respectively. Both groups II, and III revealed; a highly significant raise $\mathrm{P}<0.01$, and nonsignificant changes in the levels of creatinine compared to the control group I, respectively. Furthermore, they also revealed; a significant raise $\mathrm{P}<0.05$, and a highly significant raise $\mathrm{P}<0.01$ in levels of urea compared to the control group I, respectively (Figure 17).

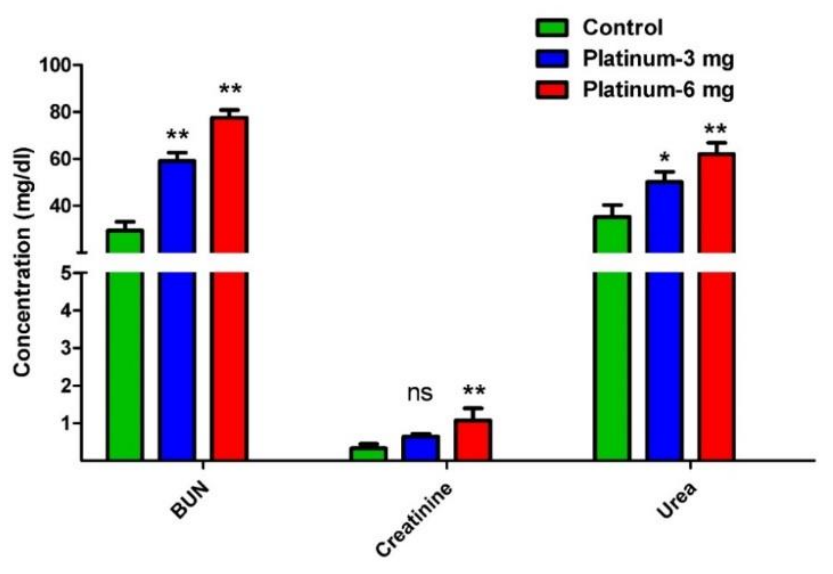

Figure 17: Explaining the effect of two doses 3 and $6 \mathrm{mg} / \mathrm{kg}$ b.w. of a Platinum on the levels of motherly serum BUN, Creatinine, and Urea. The drug was administrated to the pregnant mice at the days $7^{\text {th }}, 12^{\text {th }}$, and $17^{\text {th }}$ of gestation. The results were expressed as mean \pm standard deviation (SD), $(\mathrm{n}=3)$, ns - non-significant. The values were considered significant at $* \mathrm{P}<0.05$, and a highly significant at $* * \mathrm{P}<0.01$ compared to the control group I. Dunnett's test was used to show the differences by comparing the mean of each concentration of experimental groups II, III to the mean of the control group I.

\section{Discussion}

The prevailing data revealed several lesions in the maternal liver of both groups II and III including ; vacuolation, apoptosis, an increase of the eosinophil's of some hepatocytes in the portal area, congestion of the central vein, and dilatation of the sinusoids. The current findings were comparable to the findings of those (22-27), how indicates that injecting rodents (rats) with the platinum- base anticancer at certain doses can induce programmed cell death, and some structural changes in the liver. The current findings were contrary to the findings of (25). The occurrence of previous lesions in the current study may due to the interaction of the drug with an antioxidant defense system that induces highly reactive oxygen species formation (28). Besides, the drug generates cellular toxic effects, including functional and structural mitochondrial damage, apoptosis induction, CA homeostasis disruption, and the participation of pro-inflammatory genes like COXII, that play an important role in the Platinum hepatotoxicity process (29).

Microscopic examination of the fetal liver of both groups II, and III exhibited several lesions outlined with the congestion of blood capillaries, and degeneration of the primitive hepatocytes. The severity of histological injuries was dose-dependent -manner. The current findings were agreed with the findings of the authors (30-33), but they were 
in contrast with the findings of (34). Previous lesions occurring in the current study may be explained by the fact that the selected drug is characterized with its low molecular weight, and its ability to cross the placenta. Thus, the medication enters the fetal body, and reaches the liver through the circulatory system. Therefore, the selected drug will be distributed and accumulated in the liver cells resulting in high oxidative stress, which in turn destroys the liver cells (35) or it may be attributable to doses, and duration of exposure. (36).

The maternal kidney of both groups II and III explained remarkable lesions including; degeneration of the proximal convoluted epithelium, expansion of Bowman's space, and inflammatory cells infiltration within interstitial tissue, respectively. The current findings were similar to those of $(37,38)$. Whilst, the current findings were in contrast with the findings of those (39-41), where all authors confirmed that the drug cause loss of brush border, glomerular sclerosis, and interstitial fibrosis, respectively. Kidney lesions in the current study may due to the drug had a bad effect on sodium water transport, which may cause early renal tissue injuries (42). The drug molecule is uncharged, that made it freely flow through the glomeruli, and taken up by renal tubular cells, so the drug reaches its highest concentration in the outer part of the renal cortex (43).

The fetal kidney of group III showed degeneration of the primitive renal tissue, and congestion of the blood capillaries. The current findings were in agreement with the findings of (32), but they were indifferent with the findings of (6), who explained that the administration of cisplatin to the rats (therapeutic doses) throughout gestation induces dilatation of the renal pelvis, and several lesions in the lung and heart. The current findings also agreed with what confirmed by (44).u Lesions' occurrence in the current study may due to that platinum-based antitumour has three characteristics. These characteristics are as follows; low molecular weight, lipid-soluble, and they are nonionized (35). Thus, these drugs easily spread through the placenta by passive diffusion, and reaches the fetal body through the bloodstream. It is worth noting that the concentration of these drugs in the fetal blood circulation is lower than in the mother's blood (45).

The current study revealed a significant $\mathrm{P}>0.05$, and a highly significant $\mathrm{P}<0.01$ reduction in the maternal body weight of both groups II and III compared to the control group I, respectively. Maternal kidneys of group III showed; a significant reduction $\mathrm{P}<0.05$ in their weight compared to the control group I. The findings also showed a highly significant reduction $\mathrm{P}<0.01$ in the fetal body weight of group III. The current findings were agreed with those of (46-48), where all authors confirm the effect of the Platinum on the rodent's weight. Moreover, the weight reduction in the maternal bodies, liver, kidneys, and embryos in the current study may due to that Platinum alters lipid metabolism, and induce weight loss in both of the mothers, and fetuses (49).
Alternatively, may due to that Platinum increase the markers of lipolysis in the white adipose tissue (WAT), B-oxidation, and suppressed lipogenesis in the liver. Thus, these markers had regulated by other factors in a tissue-specific manner. On the other hand, maybe because of the decrease in the ability to concentrate urine resulting in papillary hypertonicity, that is considered the main reason for losing body weight $(49,50)$.

Biochemically, the maternal serum of group III showed; a highly significant increase $\mathrm{P}<0.01$ in the levels of AST, ALP, and a very highly significant increase $\mathrm{P}<0.001$ in the level of ALT. Thus, the rise in the levels of these enzymes indicates disruption of liver function. Whilst, both groups II and III showed; a highly significant increase $\mathrm{P}<0.01$ in the concentrations of BUN, creatinine, and urea, respectively. The current findings were similar to those of $(51,52)$. The biochemical changes in the current study may be due to that the drug causes a reduction in the glutathione concentration (which plays an important role in removing many toxic metabolites) in the tissue of the maternal liver, kidneys, and that seems to have the main role in disturbing the cellular antioxidant regulation. The decrease in the glutathione levels leads to the accumulation of toxic materials in the living cells, which in turn cause cellular dysfunction (53).

\section{Conclusions}

Compared to the benefits of using anticancer drugs in cancer therapy at high doses, it might cause many adverse effects. Thus, the consequence of the drug depended on the doses, and the exposure period. The recent research established the toxic effect of the Platinum drug over both doses of 3 and $6 \mathrm{mg} / \mathrm{kg} \mathrm{b} . \mathrm{w}$ on pregnant mice administered at certain days of gestation. The medication had injured both mothers fetuses 'liver and kidneys, especially if used during delicate pregnancy stages including; the first trimester, the second trimester, and the third trimester. The selected drug alters the regulation of the antioxidant levels in the living body. Thus, the drug should be taken under special medical care, and the patient must adhere to the certain dose prescribed by the specialist.

\section{Acknowledgment}

The authors are very grateful to the University of Mosul, the College of Education for the Pure Science, Department of Biology for their support, which helped to improve the quality of this work.

\section{Conflict of interest}

The authors declare that there are no conflicts of interest. 


\section{References}

1. Frezza M, Hindo S, Ping D. Novel metals and metal complexes as platforms for cancer therapy. Cur Pharm Des. 2010;16(16):1813-1825. Doi: $10.2174 / 138161210791209009$

2. Ravindra P, Bhiwgade DA, Kulkarni S, Rataboli PV, Dhume, CY. Cisplatin induced histological changes in renal tissue of rat. J Cell Anim Bio. 2010;4(7):108-111. Doi: 10.5897/JCAB.9000003

3. Mendez LE, Mueller A, Salom E, Gonzalez- Quintero VH. Paclitaxel, and carboplatin chemotherapy administration during pregnancy for advanced epithelial ovarian cancer.Obstet Gynecol. 2003;102:12001202. Doi: $10.1016 / \mathrm{s} 0029-7844(03) 00698-7$

4. Rahmani BR, Moslem AR, Rahmani MR, Askari B. The effect of food intake during labour on maternal outcomes:A randomized controlled trial. Ofogh-e- Danesh. GMUHS J.2009;15:17-23. Doi: 10.4103/ijnmr. IJNMR $213 \quad 15$

5. Aoki K, Kajiura S, Matsumoto Y. Preconceptional natural -killer-cell activity as a predictor of miscarriage. Lancet. 1995;345:1340-1342. Doi: 10.1016/s0140-6736(95)92539-2

6. Haricharan S, Jie D, Hein S, Jay PR, Zhijun DU, Michael T, Kimberly H, Susan G, Huang S, Rachel A, Wendy W, Sonali J, Virginia FB, Gutierrez C, Hong Z, Schedin PJ, Osborne K, Tweardy Yl. Mechanism and preclinical prevention of increased breast cancer risk caused by pregnancy. Human Bio Med. 2013;1(9):122-142. Doi: 10.7554/eLife.00996

7. Siddik ZH. Cisplatin:mode of the cytotoxic and molecular basis of resistance. Oncogene. 2003;22:7265-7279. Doi: 10.1038/SJ.onc. 1206933

8. Chibber IS, Naseem I. The ameliorative effect of riboflavin on the cisplatin-induced nephrotoxicity and hepatotoxicity under photo illumination. Food Chem Toxicol. 2010;48(8-9):2052-2058. Doi: 10.1016/j.fct.2010.05.004

9. Zecca A, Cafaggi S, Mariggio MA, Vannozzi MO, Ottone NI, Bocchini V, Caviglioli G, Ciale M. Reduction of cisplatin hepatotoxicity by procainamide hydrochloride in rat. Eur J Pharmacol. 2002;44(3):265272. Doi: $10.1016 / \mathrm{s} 0014-2999(02) 01537-6$

10. Series K, Weqrzynow E, Jassem J. Paclitaxel and cisplatin chemotherapy for ovarian cancer during pregnancy:case report and review of the literature. Arch Gynecol Obstet. 2011;28(1):97-100. Doi: 10.1007/s00404-011-1855-4

11. Yong II, Kim KT. Gynaecologic malignancy in pregnancy. Obstet Gynecol Sci. 2013;56(5):289-300. Doi: 10.5468/ogs.2013.56.5.289

12. Yoshinaka A, Fukasawa I, Sakamoto T. The fertility and pregnancy outcomes of patients who underwent preservative operation followed by adjuvant chemotherapy for malignant ovarian tumours. Gyne Obst. 2000;264(3):124-127. Doi: 10.1007/s004040000094

13. Longo VD, Mattson MP. Fasting:molecular mechanisms and clinical applications. Cell Metab. 2014;19(2):181-192. Doi: 10.1016/j.cmet.2013.12.008

14. Naziroglu M, Senol N, Ghazizadeh V, Yuruker V. Neuroprotection induced by $\mathrm{N}$-acetylcysteine and selenium against traumatic brain injury-induced apoptosis and calcium entry in the hippocampus of the rat. Cell Mol Neurobiol. 2014;34,895-903. Doi: 10.1007/s10571-0140069-2

15. Kursunluoglu G ,Kayali HA, Taskiran D. The effect of cisplatin of toxicity and capsaicin on electron transport chain in liver and kidney of Sprague Dawley rats. Cell Biochem Biophys. 2014;69(3):707716. Doi: $10.1007 / \mathrm{s} 12013-014-9857-\mathrm{Z}$

16. Singh SV, Srivastava SK, Choi S, Lew KL, Sulforaphane-induced cell is death in the human prostate cancer cell death is initiated by reactive oxygen species. J Biol Chem. 2005;280:19911. Doi: 10.1074/jbc.M412443200

17. Ghaemmaghami F, Hasanzadeh M. The good fetal outcome of pregnancy with Gynecologic cancer condition: Cases and literature review. Int J Gynecol Can. 2006;16(1):1-7. Doi: 10.1111/j.15251438.2006.00510.x
18. Salah BA. Histopathological effect of fluoxetine drug on the brain of pregnant mice and their embryos. Iraqi J Vet Sci. 2020;34(1):71-76. Doi: $10.33899 /$ ijvs.2019.125467.1006

19. Ali MO, El- Nahass E, Diamond MO, Desouki G. Embryo toxic effect diabetes mellitus. Al-Azhar Med J. 1989;17(4):421-228. Doi: $10.12816 / 0026270$

20. Aston WJ, Hope ED, Nowak Ak, Robinson BW, Lake RA, lesterhuis WJ.A systematic investigation of the maximum tolerated a dose of cytotoxic supportive care in mice. BMC Cancer. 2017;17:684. Doi: 10.1186/s12885-017-3677-7

21. Al-Haaik AG. A gross anatomical and histological study of pancreas in adult Kestrel (Falco tinnunculus). Iraqi J Vet Sci. 2019;33(2):175180. Doi: 10.33899 /ijvs.2019.162960

22. Santos NA, Martins NM, Curti C, Pires B ML, Santos AC. Dimethylthiourea protects against mitochondrial oxidative damage induced by cisplatin in the liver of the rat. Chem Biol Interact. 2007;170(3):177-68.

23. Mir M, Arab MR, Shahraki MR, Mashhad MA, Salar MS, Aral FS, Karimfar MH. Toxic effects of cisplatin on hepatocytes and liver enzymes of the rat. Anat Sci. 2015;12(4):171-175. Doi: 10.7314/APJCP.2014.15.17.7389

24. Soni H, Kaminski, D, Gangaraju R, Adebiyi A. Cisplatin-induced oxidative stress stimulates renal Fas ligand shedding. Ren Fail. 2018;40(1):314-322. Doi: 10.1080/0886022X.2018.1456938

25. El-Sayyad HI. Histopathological effects of cisplatin, doxorubicin and 5 -flurouracil (5-FU) on the liver of male albino rats. Int J Biol Sci. 2009;5(5):466-473. Doi: 10.7150/ijbs.5.466

26. $\mathrm{Lu} \mathrm{Y}$, Cederbaum.Cisplatin-induced hepatotoxicity is enhanced by elevated expression of cytochrome P450 2E1. Toxi Sci. 2005;89(2):515-523. Doi: 10.1093/toxsci/kfj031

27. Kamble PR, Bhiwgade D. Cisplatin-induced histological and ultrastructural alternation in liver tissue of rat. J Cytol Hist. 2011;2:128. Doi: $10.4172 / 2157-7099.1000128$

28. Ezz-Din D, Garbry A, Farrage ARH, Abdel Moneim E. Physiological and histological impact of Azadirachta indica (neem) leaves extract in a rat model of cisplatin-induced hepatic and nephrotoxicity. J Med plant. 2011;5(23):5499-5506. Doi: 10.5897/JMPR.9000980

29. Palipoch SC, Punsawad P, Koomhin P, Suwannalert P. Hepatoprotective effect of curcumin and alpha-tocopherol against cisplatin-induced oxidative stress. BMC Com Med. 2014;14(1):111. Doi: $10.1186 / 1472-6882-14-111$

30. Gerschenson M, Paik CY, Gaukler E, Diwan BA, Poirier MC. Cisplatin exposure induces mitochondrial toxicity in pregnant rats and their fetuses. Rep Toxi. 2001;15(5):525-531. Doi: 10.1016/s08906238(01)00156-3

31. Ognio J, Chiavarina B. Study of the feasibility of the treatment with procainamide hydrochloride and cisplatin in pregnant mice.ChemicoBiological Inte. 2007;164(3):232-40. Doi: 10.1016/j.cbi.2006.10.001

32. Keller KA, Aggarwal SK. Embryotoxicity of cisplatin in rats and mice. Toxicol Apple Pharmacol. 1983;30(2):245-256. Doi: 10.1016/0041008x(83)90305-8

33. Kohler C, Oppelt P, Favero G. How much platinum passes the placental barrier? Analysis of cervical cancer during pregnancy. Amer J Obst Gyn. 2015;213(2):206-206. Doi: 10.1016/j.ajog.2015.02.022

34. Yeh J, Kim BS, Persie J. Reproductive toxic effect of cisplatin and its modulation by the antioxidant sodium 2-Mercaptoethanesulfonate (Mesna) in female rats. Rep Bio Insi. 2011;5:17-27. Doi: 10.4137/RBI.S7663

35. Amant F, loibl S, Neven P, Van Calsteren K. Brest cancer in pregnancy. Lancet. 2012;370:570-579.

36. Yuen P M, Ng PS, Leung Pl, Rogers MS. The outcome in Laparoscopic management of persistent adnexal mass during the second trimester of pregnancy. Surg Endosc. 2004;18:1354-1357. Doi: 10.1007/s00464003-8283-X

37. Haler ZV, Perse M. Cisplatin-induced rodent model of kidney injury:characteristics and challenges. Bio Med Res Inter. 2018;20(18):29. Doi: $\underline{10.1155 / 2018 / 1462802}$ 
38. Ozkok A, Edelstein CL. Pathology of cisplatin-induced acute kidney injury. Biomed Res Int. 2014;2014:967826. Doi: $10.1155 / 2018 / 1462802$

39. Miller RP, Tadagavadi RK, Ramesh G, Reeves WB. Mechanism of cisplatin nephrotoxicity. Toxins. 2010;2:2490-2518. Doi: 10.3390/toxins 2112490

40. Hultstrom M, Becirovic M, Jonsson S. Comparison of acute kidney injury of different aetiology reveals an in-common mechanism of tissue damage. Physiol Genomics. 2018;50(1):127-141. Doi: 10.1152/physiolgenomics. 00037

41. Giuseppa M, Giuseppe C, Anna C, Michele P, Silvia C, Giuseppina C, Leonardo DM, Mario M. Cisplatin-induced kidney injury in the rat:1carnitine modulates the relationship between MMP-9 and TIMP-3. Expt Toxicol Pathol. 2009;6:183-188. Doi: 10.1016/j.etp.2008.07.004

42. Lajer H,Kristensen M, Hansen HH. Magnesium depletion enhances cisplatin nephrotoxicity. Can Chemother Pharmacol. 2005;56(5):535542. Doi: $10.1007 / \mathrm{s} 00280-005-1010-7$

43. Townsend DM, Tew KD, HeL, King JB, Hanigan MH. Role of glutathione S-Transferase $\mathrm{Pi}$ in cisplatin-induced nephrotoxicity. Biomed Pharmacother. 2009;63:79-85. Doi: 10.1016/j.biopha.2008.08.004

44. Zazuli Z, Vijverberg S, Maitland-van der zee A. Genetic variation and cisplatin nephrotoxicity: A systematic review. Front Pharmacol. 2018;9:1111. Doi: 10.3389/fphar.2018.01111

45. Eshkoli T, Sheiner E, Ben-Zvi Z, Holcberg G. Drug transport across the placenta. Curr Pharm Biotech. 2011;12(5):707-714. Doi: 10.2174/138920111795470877

46. Guindon J, Deng L, Baochang F, Wager J. Optimization of cisplatin model of chemotherapy-induced peripheral neuropathy in mice, which use of vitamin $\mathrm{C}$ and sodium bicarbonate to pretreatments to reduce nephrotoxicity and improve animal health status. Molecular Pain. 2014;10(1):56. Doi: 10.1186/1744-8069-10-56

47. Soni KK, Kim Hk, Choi BR, Karma KK, You JH, Cha JS, Shin YS, Lee SW, Kim CY, Park JK. Dose-dependent effects of cisplatin on the severity of testicular injury in Sprague Dawley rats:reactive oxygen species and endoplasmic reticulum stress. J Drug Design Deve Thera. 2016;2016(10):3959-3968. Doi: 10.2147/DDDT.S120014

48. Nasiri M, Sottani N, Mazahen S., Maleki M, Talebi A, Gharibi F, Nematbakhsh $\mathrm{M}$. The role of gamma aminobutyric acid in cisplatininduced nephrotoxicity in streptozotocin-induced diabetic rats. Adv Biomed Res. 2017;6:96. Doi: 10.4103/2277-9175.211834

49. Garcia JM, Scherer T, Chen Ji-an, Guillory B, Nassif A, Popusha V, Smiechowska J, Asnicar M, Buettner C and Smith R G. Inhibition of cisplatin -Induced lipid catabolism and weight loss by Ghrelin in male mice. End Soci. 2013;22(3):99-101. Doi: 10.1210/en.2013-1179

50. Seaman F, Sawhney P, Giammona CJ, Richburg JH. Cisplatin-induced plus of germ cell apoptosis precedes long-term elevated. Apoptosis. 2003;8(1):101. DoiI: 10.1023/a:1021734604913

51. Longchar A, Prasad SB. Biochemical changes associated with ascorbic acid-cisplatin combination therapeutic efficacy and protective effect on cisplatin-induced toxicity in tumor-bearing mice. Toxicol Rep. 2015;7(2):489-503. Doi: 10.1016/j.toxrep.2015.01.017

52. Chengwei NI, Man MI, Xiao HI, Zimin WV, Hangyan LV. Hyperin protects against cisplatin-induced liver injury in mice. Acta Cir Bras. 2017;32(8):633-640. Doi: 10.1590/s0102-865020170080000005

53. Ateşşahin A1, Karahan I, Türk G, Gür S, Yilmaz S, Ceribaşi AO. Protective role of lycopene on cisplatin-induced changes in sperm characteristics, testicular damage, and oxidative stress in rats. Reprod Toxicol. 2006;21(1):42-7. Doi: 10.1016/j.reprotox.2005.05.003

\section{التغيرات النسجية المرضية وبعض التيوض التأثيرات الكيموحيوية لعقار البلاتينيوم على كبالئ وكلية الفئران الحوامل Mus muscullus واجنتها لينوانيا}

$$
\text { بيذاء عبد العزيز محمد صالح و حنان صديق سعدون }
$$

قسم علوم الحياة، كلية التربية للعلوم الصرفة، قسم علوم الحياة، كلية التربية للعلوم الصرفة، جامعة الموصل، الموصل، العراق

الخلاصة

أجريت الدراسة الحالية للتحري عن تأثثر جر عتين هما ب و 7 ملغم

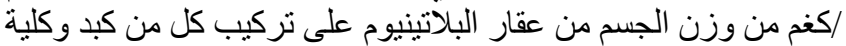

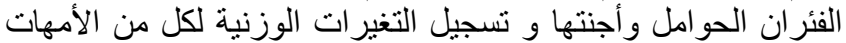

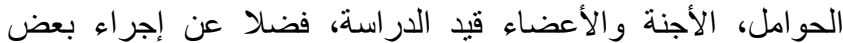
الفحوص الكيموحيوية. استخدمت ثثلاثون فأر حامل في الدراسة الأدة الحالية

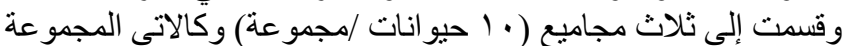

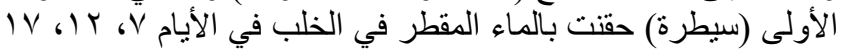

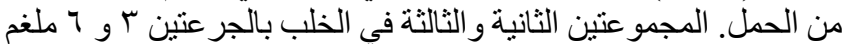

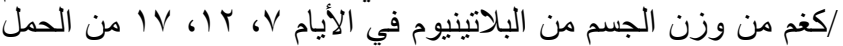

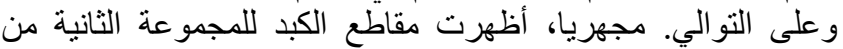

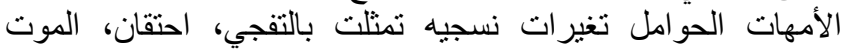

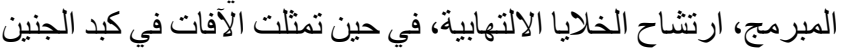

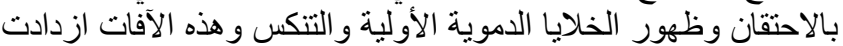
عند التركيز آملغم /كغم من وزن الجسم في كبد الأمهات وأجنتها. و أظهرت مقاطع الكلية للمجموعة الثانية من الأمهات الحوامل الته و أجنتها

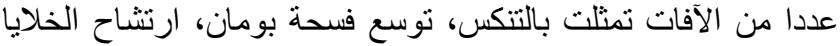

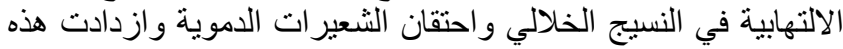

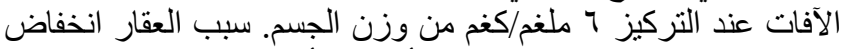

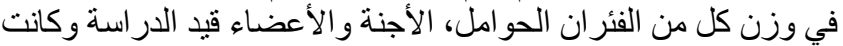

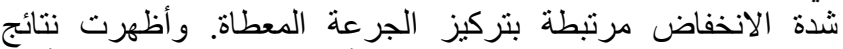

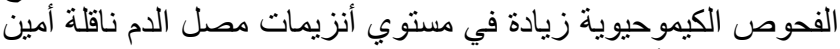

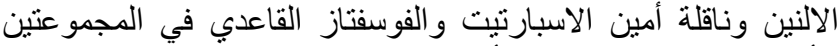
الأولى والثانية، فضلا عن أن الزيادة في مسنوي كل من نينان نيتروجين

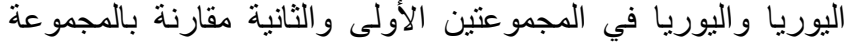

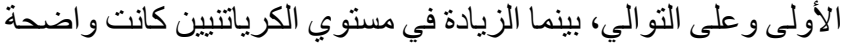

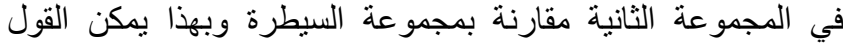

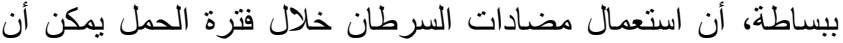

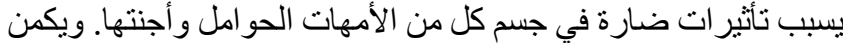
خطر هذه العقاقير في كونها تعبر الحاجز المشيمي وتصل فئ إلى الجنين،

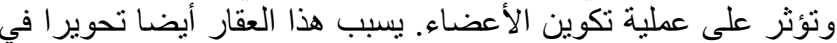

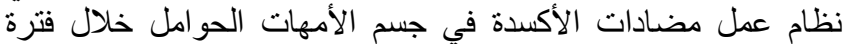
العلاج، وبهذا يجب اخذ هذا العقار تحت المتابعة و الإشر اف الطبي. 